\title{
KARAKTERISASI SIFAT FISIS DAN MIKROSTRUKTUR PAPAN GIPSUM DENGAN VARIASI KOMPOSISI LATEKS
}

\author{
ETY JUMIATI *, ABDUL HALIM DAULAY, NUR'AINI FADILLAH \\ ${ }^{1}$ Jurusan Fisika, FST, Universitas Islam Negeri Sumatera Utara Medan \\ Jl. Lapangan Golf No.120, Kp. Tengah, Kec. Pancur Batu, Kabupaten Deli Serdang, \\ Sumatera Utara \\ *email : etyjumiati87@gmail.com
}

\begin{abstract}
Abstrak. Papan gipsum merupakan salah satu produk lanjutan dari material gipsum dengan campuran serat/fiber atau bahan lainnya. Papan Gipsum memiliki kelemahan pada sifat fisisnya yang mudah menyerap air. Maka dari itu, perlu adanya inovasi dalam pembuatan papan gipsum yang akan menghasilkan mutu yang lebih baik lagi. Pembuatan papan gipsum dapat memanfaatkan bahan limbah seperti tempurug kelapa dan sekam padi serta lateks sebagai perekatnya. Pencampuran bahan papan gipsum meliputi: gipsum, tempurung kelapa, dan sekam padi yang digunakan yaitu 70\%, 15\%, 15\% dengan variasi lateks $10 \%, 12 \%, 14 \%, 16 \%, 18 \%$ dengan FAS 0,5 serta pengeringan selama 28 hari. Dengan parameter uji sifat fisis meliputi: kerapatan dan pengembangan tebal, dan pengujian mikrostruktur untuk mengetahui morfologi sampel papan gipsum. Analisis sifat fisis papan gipsum diperoleh hasil yang optimal yaitu pada sampel A dengan variasi komposisi lateks $10 \%$ didapatkan nilai kerapatan sebesar $1,35 \mathrm{~g} / \mathrm{cm}^{3}$, dan pengembangan tebal sebesar 5,03\% yang memenuhi Standar SNI 01-4449-2006. Sedangkan mikrostruktur menghasilkan gambar morfologi yang menunjukkan sebaran yang tidak homogen, terbentuk aglomerasi partikel, dan zat pengotor.
\end{abstract}

Kata kunci: lateks, papan gipsum, sekam padi, sifat fisis dan tempurung kelapa

\begin{abstract}
Gypsum board is one of the advanced products of gypsum material with a mixture of fiber/fiber or other materials. Gypsum board has a weakness in its physical properties that easily absorb water. Therefore, there is a need for innovation in the manufacture of gypsum boards that will produce even better quality. The manufacture of gypsum board can utilize waste materials such as coconut shells and rice husks and latex as adhesives. The mixture of gypsum board materials including: gypsum, coconut shell, and rice husk used was $70 \%, 15 \%, 15 \%$ with latex variation $10 \%, 12 \%, 14 \%, 16 \%, 18 \%$ with FAS 0.5 and drying for 28 days. The parameters of the physical properties test include: density and thickness expansion, as well as microstructural testing to determine the morphology of the gypsum board sample. Analysis of the physical properties of gypsum board obtained optimal results, namely in sample A with a variation of $10 \%$ latex composition, the density value was $1.35 \mathrm{~g} / \mathrm{cm}^{3}$, and the thickness expansion was $5.03 \%$ which met the SNI Standard 01-4449-2006. While the microstructure produces morphological images that show inhomogeneous distribution, particle agglomeration forms, and impurities.
\end{abstract}

Keywords: latex, gypsum board, rice husk, physical properties and coconut shell

\section{Pendahuluan}

Gipsum merupakan salah satu mineral non logam yang berbentuk kristalin, serabut dan masif yang terbentuk akibat penguapan air laut. Gipsum sangat mudah didapatkan di alam, biasanya banyak terkandung dalam batuan-batuan sedimen dan batuan lunak. Gipsum memiliki komposisi Kalsium Oksida $(\mathrm{CaO})$ yang paling

JIIF (Jurnal Ilmu dan Inovasi Fisika), ISSN: 2549-0516 
tinggi yaitu $32,57 \%$, dan diikuti kalsium $23,28 \%$, air 20,93\%, sulfur $18,62 \%$, dan hidrogen 3,34 (A. Rusdianto).

Menurut M. Yoyok Suhandoko, tempurung kelapa memiliki kandungan lignin sebesar $29,4 \%$. Sedangkan sekam padi dan tempurung kelapa dapat digunakan sebagai bahan tambahan pada pembuatan papan gipsum dikarenakan memiliki serat dan silika yang cukup tinggi. Sekam Padi merupakan limbah yang dihasilkan oleh tempat penggilingan padi. Sekam padi adalah kulit terluar dari tanaman padi. Biasanya sekam padi hanya digunakan untuk bahan makan ternak. Sekam padi memiliki kandungan serat yang paling tinggi sebesar 35,68\%, dan kandungan lainnya seperti: oksigen $33,64 \%$, karbohidrat 33,71 , abu $17,71 \%$, silica $16,98 \%$, dan kadar air 9,02\%. Untuk menaikkan mutu dan kualitas dari papan gipsum dapat digunakan bahan perekat lateks. Lateks merupakan suatu larutan koloid yang memiliki dua komponen susunan bahan lateks. Dua komponen tersebut yaitu serum dan bahan-bahan bukan karet seperti kandungan air, enzim, garam, dan protein (Gurning).

Papan gipsum adalah produk jadi yang terbuat dari serat/fiber dan campuran lainnya lainnya (Ridho Pratama). Berikut dapat dilihat pada Tabel 1. Standar Kualitas Papan Gipsum sesuai dengan SNI 01-4449-2006.

Tabel 1. Standar Kualitas Papan Gipsum Sesuai SNI 01-4449-2006

\begin{tabular}{cccc}
\hline \multirow{2}{*}{ No } & Sifat Fisis dan Mekanik & \multicolumn{2}{c}{ Standar Mutu } \\
\cline { 3 - 4 } & & PSKS & PSKT \\
\hline 1 & Densitas & $0,04-0,84 \mathrm{~g} / \mathrm{cm}^{3}$ & $>0,84 \mathrm{~g} / \mathrm{cm}^{3}$ \\
2 & Pengembangan Tebal & $<10 \%$ & - \\
\hline
\end{tabular}

\section{Metode Penelitian}

Metode yang digunakan dalam penelitian ini yaitu eksperimental dengan penambahan dan penggabungan bahan limbah tempurung kelapa dan sekam padi dan memvariasikan perekat yaitu lateks untuk melihat perubahan fisis dan mikrostruktur produk papan gipsum yang dihasilkan. Adapun alat-alat yang digunakan yaitu: beaker glass, spatula, timbangan digital, alat press manual, alat cetakan papan gipsum, jangka sorong, dan UTM (Universal Testing Machine). Sedangkan bahan yang digunakan yaitu: serbuk sekam padi, serbuk tempurung kelapa, lateks, dan air.

Pembuatan papan gipsum memiliki beberapa proses, diantaranya: proses pencampuran bahan, proses pencetakan dan pengepressan, dan proses pengeringan, serta proses pengujian. Proses pertama tepung gipsum dicampurkan dengan bahan pengisi berupa serbuk limbah sekam padi dan tempurung kelapa dengan komposisi bahan $70 \%, 15 \%, 15 \%$ dengan faktor air semen 0,5. Setelah itu, memvariasikan perekat lateks dengan variasi komposisi $10 \%, 14 \%$, dan $18 \%$. Proses kedua papan gipsum dicetak dengan menggunakan cetakan $(5 \times 5 \times 10,7) \mathrm{cm}^{3}$ dan $(10 \times 10 \times 0,7) \mathrm{cm}^{3}$ lalu papan gipsum dipress menggunakan alat press manual. Proses ketiga papan gipsum yang telah dicetak kemudian dikeringkan selama 28 hari dengan berada pada suhu ruangan. 
Proses selanjutnya dilakukan pengujian papan gipsum dengan parameter uji diantaranya: kerapatan, pengembangan tebal, dan SEM (Scanning Electron Microschopy). Pengujian papan gipsum menggunakan 3 kali pengulangan. Pengukuran kerapatan dan pengembangan tebal diilakukan sesuai acuan SNI 014449-2006 dengan cara merendamkan sampel papan gipsum kedalam wadah yang berisi air. Perhitungan kerapatan dan pengembangan tebal menggunakan persamaan berikut;

$$
K=\frac{B}{I}
$$

dengan $\mathrm{K}$ adalah kerapatan benda $\left(\mathrm{g} / \mathrm{cm}^{3}\right)$, B adalah massa benda $(\mathrm{g})$, I adalah isi $\left(\mathrm{cm}^{3}\right)$.

$$
P T=\frac{T_{2}-T_{1}}{T_{1}} \times 100 \%
$$

dengan PT adalah pengembangan tebal (\%), T1 adalah tebal sebelum perendaman $(\mathrm{cm})$, dan T2 adalah tebal sesudah perendaman $(\mathrm{cm})$.

\section{Hasil dan Pembahasan}

Hasil analisis pengukuran kerapatan sampel papan gipsum tercantum Tabel 2. Pengukuran kerapatan bertujuan untuk melihat seberapa rapat papan gipsum yang dihasilkan. Semakin rapat atau bagus nilai kerapatan yang dihasilkan maka papan gipsum memiliki mutu yang baik. Namun, semakin rendah nilai kerapatan yang dihasilkan maka mutu papan gipsum tidak baik. Dapat dilihat pada grafik 1 di atas, hasil kerapatan mengalami penurunan yang signifikan. Dimana penurunan ini disebabkan oleh variasi perekat lateks yang semakin besar. Dari hasil analisis yang di dapat semakin besar variasi lateks yang diberikan maka hasil kerapatan semakin rendah. Menurut Djoko Purwanto 2016, penurunan nilai kerapatan dapat sebabkan oleh rongga atau pori yang bertugas mengikat ikatan antar molekul.

Tabel 2. Hasil Kerapatan Sampel Papan Gipsum

\begin{tabular}{cccc}
\hline No & Sampel & Hasil Pengukuran & Standar Mutu SNI \\
\hline 1. & A & $1,35 \mathrm{~g} / \mathrm{cm}^{3}$ & \\
\hline 2. & B & $1,25 \mathrm{~g} / \mathrm{cm}^{3}$ & $0,40-0,84 \mathrm{~g} / \mathrm{cm}^{3}$ \\
\hline 3. & C & $1,21 \mathrm{~g} / \mathrm{cm}^{3}$ & \\
\hline 4. & D & $1,16 \mathrm{~g} / \mathrm{cm}^{3}$ & \\
\hline 5. & E & $1,11 \mathrm{~g} / \mathrm{cm}^{3}$ & \\
\hline
\end{tabular}

Hasil analisis pengukuran kerapatan Sampel papan gipsum tercantum Tabel 3. Pengukuran pengembangan tebal bertujuan untuk melihat seberapa baik papan gipsum dalam menyerap air setelah perendaman. Dapat dilihat pada grafik 2 di atas, hasil pengembangan tebal mengalami kenaikkan yang signifikan. Dimana kenaikkan nilai pengembangan tebal yang terjadi memaparkan bahwa semakin besar variasi komposisi lateks yang diberikan maka nilai pengembangan tebal yang dihasilkan yaitu lebih tinggi dalam artian lebih mudah menyerap air. Pada umumnya, semakin tinggi nilai pengembangan tebal maka akan semakin tinggi juga sifat daya serap airnya, dan sebaliknya semakin rendah nilai pengembangan tebal maka sifat daya serap airnya semakin rendah (Sijabat). 
Tabel 3. Hasil pengembanngan tebal sampel papan gipsum

\begin{tabular}{|c|c|c|c|}
\hline No & Sampel & Hasil Pengukuran & Standar Mutu SNI \\
\hline 1. & A & $5,03 \%$ & \multirow{5}{*}{$<10 \%$} \\
\hline 2. & $\mathrm{~B}$ & $6,85 \%$ & \\
\hline 3. & $\mathrm{C}$ & $7,50 \%$ & \\
\hline 4. & $\mathrm{D}$ & $8,99 \%$ & \\
\hline 5. & $\mathrm{E}$ & $9,81 \%$ & \\
\hline
\end{tabular}

Hasil mikrostruktur papan gipsum diperoleh dengan menggunakan alat SEM (Scanning Electron Microschopy) dengan menggunakan perbesaran 250x pada setiap sampelnya. Hasil foto mikrostruktur dapat dilihat pada Gambar 1. Berdasarkan Gambar 1 terlihat bahwa morfologi permukaan papan gipsum tidak homogen karena masih terdapat zat-zat pengotor dan adanya gumpalan atau aglomerasi. Dari gambar 1 dapat diketahui bahwa semakin bertambah variasi lateks maka gumpalan pada morfologi foto SEM akan semakin banyak sehingga mengakibatkan ketidakmerataan partikel. Permukaan papan gipsum yang sebarannya tidak homogen dapat disebabkan oleh proses pengadukkan dan proses pengepressan yang dilakukan secara manual.
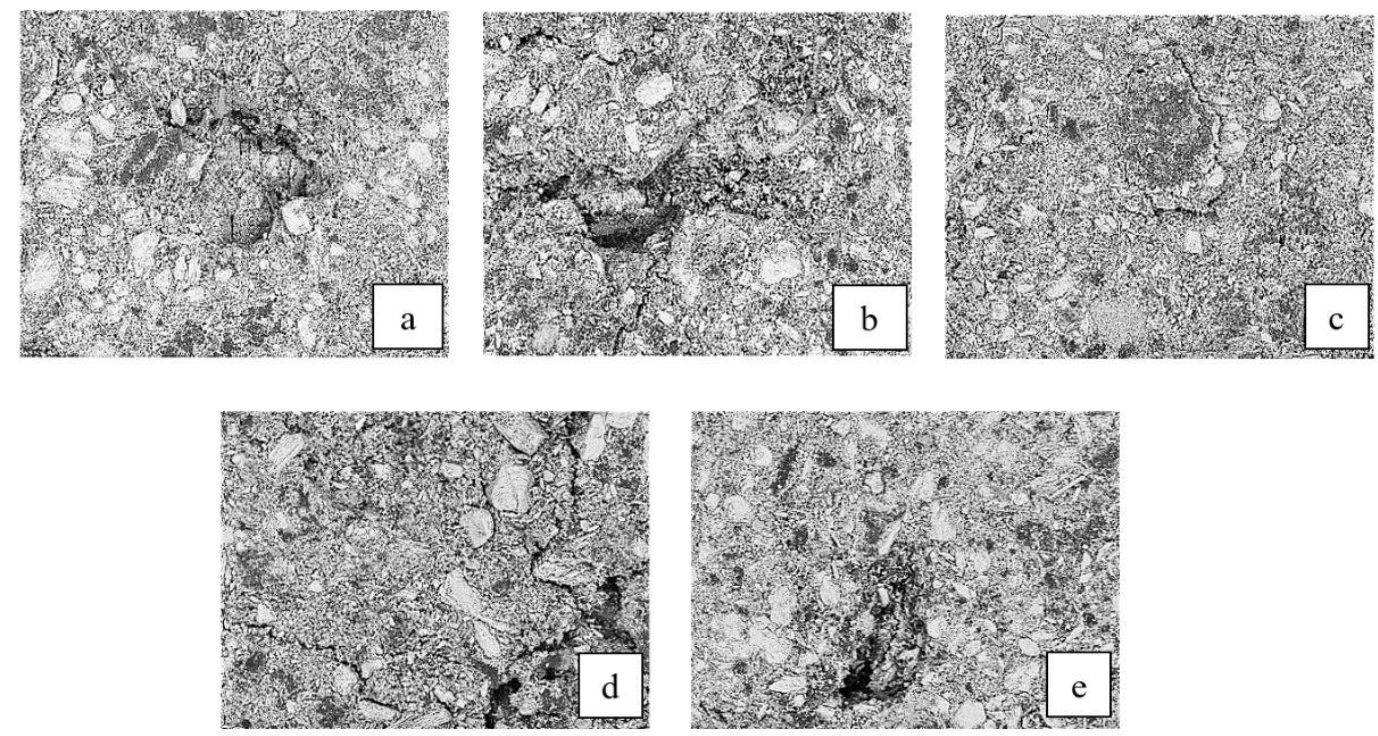

Gambar 1. Hasil Foto Mikrostruktur Papan Gipsum Perbesaran 250x (a) Sampel A, (b) Sampel B, (c) Sampel C, (d) Sampel D, (e) Sampel E

\section{Kesimpulan}

Papan gipsum dengan variasi komposisi lateks menghasilkan nilai kerapatan dan pengembangan tebal yang memenuhi acuan SNI 01-4449-2006. Dimana nilai optimal didapatkan oleh sampel A dengan nilai kerapatan sebesar 1,35 g/cm ${ }^{3}$, dan pengembangan tebal sebesar 5,03\%. Sifat fisis papan gipsum sejalan dengan hasil mikrostruktur foto SEM yang dihasilkan. Semakin bertambahnya variasi komposisi 
lateks maka semakin rendah pendistribusian partikel oleh papan gipsum yang dikibatkan terjadinya gumpalan-gumpalan yang disebabkan oleh perekat lateks sehingga menurunkan sifat fisis dari papan gipsum.

\section{Ucapan Terima Kasih}

Terima kasih saya sampaikan kepada Laboratorium Fisika Dasar UIN SU yang telah mengizinkan saya untuk melakukan penelitian dan seluruh pihak yang ikut berkontribusi dalam penelitian ini

\section{Daftar Pustaka}

1. A. Rusdianto, Pemanfaatan Serbuk Tempurung Kelapa sebagai Campuran Gipsum Plafon dengan Bahan Pengikat Lateks Akrilik, Tesis, Universitas Sumatera Utara, Medan (2011), p. 5.

2. R. Gurning, Pembuatan Spesimen Sarung Tangan Berbahan Dasar Lateks Pekat $60 \%$ dengan Pengisi Montmorillonit yang Dimodifikasi dengan Ctab, Skripsi, Universitas Sumatera Utara, Medan (2015), p. 5.

3. R. Pratama, dan M. Dirhamsyah, Nurhaida, Sifat Fisik Dan Mekanik Papan Gipsum Dari Limbah Kayu Akasia (Acacia Mangium Willd) Berdasarkan Kadar Gipsum Dan Ukuran Serbuk Kayu, JURNAL HUTAN LESTARI, Vol 7 No.1 (2019), p. 305-315.

4. Standar Nasional Indonesia. "Standar Nasional Indonesia 01-4449-2006 Papan Semen. ." n.d. 2006.

5. D. Purwanto, Sifat Fisis dan Mekanis Papan Partikel dari Limbah Campuran Serutan Rotan dan Serbuk Kayu, Jurnal Riset Industri, Vol. 10 No. 310.3 (2016) S. Hidayat, M. O. Tjia, Karakteristik Model Batere Sekunder Menggunakan Elektroda PANI-NMP, Kontribusi Fisika Indonesia, Vol. 13 No.3 (2002), p. 165-168.

6. F. I. Sijabat, J. Saragih, Halimatuddahlina, Pengaruh Ukuran Serbuk Tempurung Kelapa Sebagai Pengisi Komposit Poliester Tak Jenuh Terhadap Sifat Mekanik Dan Penyerapan Air, Teknik Kimia USU, Vol. 2 No. 3, Medan (2013), p. 31-37. 